\title{
Research
}

Margaret Kay, Shanika Wijayanayaka, Harriet Cook and Samantha Hollingworth

\section{Understanding quality use of medicines in refugee communities in Australian primary care:}

\author{
a qualitative study
}

\begin{abstract}
Background

Although refugee health issues are increasingly experienced in primary health care, few studies have explored the quality use of medicines in refugee communities even though access to and quality use of medicines is a key component of care delivery.
\end{abstract}

Aim

To identify strategies to support the quality use of medicines in refugee communities.

\section{Design and setting}

Qualitative study with primary healthcare

providers and refugee health leaders in Brisbane, Australia.

\section{Method}

Semi-structured interviews were conducted with refugee health leaders, pharmacists, practice nurses, and GPs. Data were recorded and transcribed. Thematic analysis was used to identify key barriers and facilitators for the quality use of medicines.

\section{Results}

Five barriers, including communication and language barriers, limited health literacy and financial cost, and four facilitators, including better coordination between healthcare providers and improved healthcare provider training, were identified. This study provides a rich exploration relating to medication use and examines the engagement between pharmacists and refugees, highlighting some communication concerns. It recognises the supportive role of the practice nurse and offers practical strategies for improving community knowledge about safe medicines use.

\section{Conclusion}

This preliminary study builds on previous studies investigating refugee health access and health literacy. It offers new understandings towards enhancing quality use of medicines in refugee communities and practical insights to assist the targeting of resources for future interventions.

\section{Keywords}

Australia; delivery of health care; medicines optimisation; pharmacists; practice nurses quality use of medicines; refugees.

\section{INTRODUCTION}

Resettlement of refugees is a global issue that is attracting increasing attention. 1.2 Many refugees will have been exposed to trauma and torture, with difficulties accessing food clean water, and sanitation. ${ }^{3}$ Their health issues can be multiple and complex, and may include infectious disease, nutritional deficiency, chronic disease, ${ }^{4,5}$ and mental health problems, while health access is often limited. ${ }^{3}$

Traditional countries of resettlement for refugees from all over the world include Australia, the UK, Canada, New Zealand, the Netherlands, Denmark, Finland, Norway, Sweden, and the US. ${ }^{6}$ For most of these countries primary health care is their frontline health service, and advocacy for strengthening the primary health care sector in the US is increasing. ${ }^{7}$ This sector has been championed as enabling more equitable care delivery to the most vulnerable communities.8.9 Delivering refugee health care in primary care can be supported through policy and strategic frameworks. ${ }^{10,11}$

Optimising medicines use, ensuring that the right patients get the right choice of medicine, at the right time', ${ }^{12}$ is a key issue for the safe delivery of quality health care in general,13,14 including primary health care. ${ }^{15}$ Working collaboratively, health professionals can reduce the risks associated with medicines use ${ }^{12}$ by providing

M Kay, PhD, FRACGP, Dip RACOG, senior lecturer; S Wijayanayaka, BSc, MBBS, research student, Discipline of General Practice, University of Queensland, Brisbane, Australia. H Cook, MPharm clinical pharmacist, Addensbrooke's Hospital, Cambridge, UK. S Hollingworth, PhD, MPH, senior lecturer, School of Pharmacy, University of Queensland, Woolloongabba, Australia. Address for correspondence

Margaret Kay, Discipline of General Practice, Level 8, Health Sciences Building. Building 16/901,

Royal Brisbane \& Women's Hospital Complex, accurate information and appropriate education, and enabling treatment choices by communicating effectively with their patients. $^{12}$

Australia has adopted the term "qualityuse of medicines' to encapsulate these issues. These include selecting management options wisely, choosing suitable medicines if a medicine is considered necessary, and using medicines safely and effectively. ${ }^{16}$ Timely access to medicines and enabling the quality use of medicines are two of the central objectives of Australia's National Medicines Policy.13 'Medicines' include prescription, non-prescription, and complementary medicines.

The concept of quality use of medicines resonates strongly with international literature that recognises the importance of concordance, ${ }^{17}$ with patient and provider working together in the management of health problems, including chronic disease and mental health problems. ${ }^{12,18,19}$ Medicines are frequently required for the management of acute and chronic health conditions in refugee patients. ${ }^{20,21}$ Cultural and linguistic barriers can significantly impact on the treatment received by refugees, ${ }^{22}$ but few studies have investigated the quality use of medicines in refugee communities. ${ }^{23}$

Every year Australia resettles over 13000 people through its humanitarian programme, with 13768 visas granted in 2013-2014.24 Most refugees arrive
University of Queensland, Brisbane, Queensland, Australia, 4029

E-mail: m.kay1duq.edu.au

Submitted: 6 September 2015; Editor's response: 24 November 2015; final acceptance: 27 January 2016.

CBritish Journal of General Practice

This is the full-length article (published online 10 May 2016) of an abridged version published in print. Cite this article as: Br J Gen Pract 2016; DOI: 10.3399/bjgp16X685249 


\section{How this fits in}

Optimising the use of medicines is a key element of the delivery of quality care to refugees. Currently, little is known about this issue. This qualitative study provides insights from both health providers and refugees (refugee health leaders), identifying significant barriers, including poor communication of medicines information, limited health literacy, and financial cost. Practical strategies are highlighted including interprofessiona communication between, and crosscultural training for, health providers, and the role of health leaders in community education, which can enable future resources to be targeted.

as permanent residents with access to Medicare la universal health insurance scheme that publicly funds healthcare services) and social services, but many continue to experience barriers that limit their access to quality health care. ${ }^{25,26}$ One study of medicines use with members of different refugee communities in South Australia reported barriers encountered by refugees when seeking and engaging with health services. ${ }^{27}$ The authors made 11 systemic recommendations that broadly focused on enabling health access, addressing cultural and (especially) linguistic barriers, and enhancing health literacy in refugee communities, rather than addressing issues specific to quality use of medicines.

This study was designed as a preliminary investigation with the strategic purpose of informing future quality use of medicines initiatives for refugee communities. Most health care for refugees is provided in the primary healthcare sector, ${ }^{26,28}$ so this study was intentionally located in the community. To the authors knowledge it is the first study to investigate this issue by engaging both healthcare providers and refugees. This study aims to explore the barriers to and facilitators of quality use of medicines as experienced by refugees, pharmacists, GPs, and nurses working in the primary healthcare setting.

\section{METHOD}

This qualitative study was undertaken in Brisbane, Australia, in 2013. It was designed after consultation with the Refugee Health Partnership Advisory Group with members from refugee health and refugee support services across southeast Queensland as well as members of local refugee communities. ${ }^{29}$ Most humanitarian entrants who arrive in Queensland are resettled in southeast Queensland, with nearly 4000 refugees being resettled in Brisbane from April 2010 to March 2015. ${ }^{30}$ The Refugee Health Partnership Advisory Group works closely with the Clinical Advisory Group, which is composed of primary care service providers who have extensive experience providing care to people of refugee background.

Using purposive sampling, healthcare providers with experience in health care for refugees (GPS, practice nurses, and pharmacists) were recruited through the Clinical Advisory Group. They were asked to participate and also to recruit other providers. Refugee health leaders were recruited from local refugee communities through the Refugee Health Partnership Advisory Group. They are proficient in English and have been trained in health literacy and research literacy with Mater University of Queensland Centre for Primary Health Care Innovation. The refugee health leaders are considered health leaders by their communities, are closely engaged with their communities, and have previously consulted with their communities about health issues. Refugee health leaders were therefore ideally placed to discuss issues related to their communities' health and bring a rich understanding of the breadth of health issues.

Potential participants were informed about the project and invited to participate through their respective organisations. Those who agreed to participate were contacted and given an information leaflet. After providing consent, each participant was interviewed at a mutually agreed time and place. Informed consent was confirmed in writing at the interview and confidentiality was highlighted. Participants were informed that they could leave the project at any time without penalty. Participants were given a modest shopping voucher in appreciation of their time.

A short demographic questionnaire was administered. Interviews were semistructured, using an interview guide informed by a review of the literature. All participants were asked questions relating to quality use of medicines (barriers and facilitators), with a focus on access to medicines and how medicines were used. Healthcare providers were asked about their usual practice when providing medicines to refugees, and refugee health leaders were asked about the use of medicines in their communities. Interviews lasted up to 45 minutes and were digitally recorded. The interviewers took field notes. Data were transcribed, de-identified, coded, and 
re-coded. An iterative, inductive process was used to identify emergent themes, and patterns were identified using a constant comparative method. ${ }^{31}$ Disparate views were resolved through discussion and a series of overarching themes were determined. These were then grouped into key categories of barriers and facilitators. Excel software was used for data management.

\section{RESULTS}

Twelve people were recruited: nine health providers (two GPs, three practice (registered) nurses [N], and four pharmacists [P]) and three refugee health leaders [RHL] (from Sudan, Liberia, and Burma) (Table 1). The refugee health leaders come from relatively large refugee communities in Brisbane, with significant numbers being resettled within the last 15 years. Nine overarching themes were identified (Box 1). These are presented as barriers or facilitators, but it should be noted that correction of a barrier can transform it into a facilitator. Appendix 1 provides further illustrative quotes.

\section{Barriers to access and quality use of medicines}

Five barriers were identified: communication and language constraints, cultural issues, limited health literacy, financial cost, and health system concerns.

Language and communication barriers. Communication barriers were the most common and they impacted on access and

\begin{tabular}{|c|c|c|c|c|}
\hline Code & Sex & $\begin{array}{l}\text { Country } \\
\text { of birth }\end{array}$ & $\begin{array}{l}\text { Ethnicity/ } \\
\text { cultural group }\end{array}$ & $\begin{array}{c}\text { First } \\
\text { language }\end{array}$ \\
\hline RHL1 & Female & Sudan & Nuer & Nuer \\
\hline RHL2 & Female & Burma & Burmese & Burmese \\
\hline RHL3 & Male & Liberia & Mandingo & Mandingo \\
\hline GP1 & Male & Taiwan & Chinese & Mandarin \\
\hline GP2 & Male & England & English & English \\
\hline N1 & Female & Australia & $\begin{array}{c}\text { Anglo-Saxon } \\
\text { heritage Australian }\end{array}$ & English \\
\hline N2 & Female & Australia & $\begin{array}{c}\text { Anglo-Saxon } \\
\text { heritage Australian }\end{array}$ & English \\
\hline N3 & Female & Australia & $\begin{array}{c}\text { Anglo-Saxon } \\
\text { heritage Australian }\end{array}$ & English \\
\hline P1 & Male & Ireland & Irish & English \\
\hline P2 & Male & Fiji & Fijian Indian & Hindi \\
\hline P3 & Male & Australia & Fijian Indian & English \\
\hline P4 & Female & Australia & Greek & English \\
\hline
\end{tabular}

$N=$ practice nurse. $P=$ pharmacist. $R H L=$ refugee health leader. quality use of medicines. Not being able to speak, read, or write the English language made it difficult for refugees to present their health concerns to their health provider, especially when seeking over-the-counter medicines. Language barriers affected patient safety. Refugees often left a medical consultation with a prescription without understanding the prescribed medicine:

When a person from refugee background goes to get their medication after their prescription, they don't have an interpreter with them because the interpreters are always booked for the medical appointments but not for the pharmacy's access ... there is no means of communication between them and the patient because there's no interpreter.' (RHL1)

'Over-the-counter stuff is probably more dangerous because at least at the pharmacy they will tell them how to use something before they ... because they do it with Australians and they do it with the refugees as well. Whereas I think when you buy cough medicines or 'Panadol' or all of that sort of stuff just at the counter at the supermarkets it's much more dangerous ... '(N2)

Language barriers could also affect compliance:

'They sort of come in with multiple empty boxes of medications and you're not sure really how long they've been off the medications and how much they've taken a day... whether they've taken too many or too little ... it's often very unclear and I think language barriers are ... the biggest reason for it.' (GP1)

Failure to address the linguistic barrier by the healthcare provider could prove expensive for the health system:

A refugee man ... had the beginning of renal failure so they [the hospital] were giving him an injection once a week - he had to come to us to get this injection ... \$1000 per injection. [They] gave him an 'esky' [cooler box] with his injections in it and said to him, in English "take these to your doctor" ... He bought them in to us on Monday morning. There was - you know - an inch of water in the bottom with the ice melted - the labels off all the syringes ... I rang the hospital and ... I found the person who gave it to him and she said "but I told him". I said "he can't speak English ..." "Oh no, it was written on the box." I said "he can't speak English, let alone read English!".' (N1) 


\section{Box 1. Barriers and facilitators relating to access to and quality use of medications for people of refugee background}

\section{Theme}

Language and communication barriers

\begin{tabular}{ll}
\hline Cultural barriers & $\begin{array}{l}\text { Issues related to cultural difference including cultural } \\
\text { expectations and cultural practices }\end{array}$ \\
\hline Limited health literacy & Issues related to reduced health knowledge \\
\hline Financial barriers & Issues related to cost of medications \\
\hline Health system barriers & $\begin{array}{l}\text { Issues related to understanding and navigating the health } \\
\text { system }\end{array}$ \\
\hline Coordination between & $\begin{array}{l}\text { Interprofessional communication or engagement } \\
\text { healthcare providers }\end{array}$ \\
\hline impacting on medication use \\
\hline Healthcare provider training & $\begin{array}{l}\text { Assistance with medication provided by community } \\
\text { organisations }\end{array}$ \\
\hline Provision of medicines information & Formal education about cross-cultural communication \\
& $\begin{array}{l}\text { That is, providing information about taking the medicines, } \\
\text { returning for a repeat prescription, or understanding } \\
\text { the medicine }\end{array}$ \\
\hline
\end{tabular}

Interpreters were clearly valued:

'To call up an interpreter and have them on speaker phone. Yeah ... saves a lot of misunderstanding.' (N3)

Yet interpreter services were under-used in the pharmacy and both refugees and healthcare providers described relying on non-verbal communication for essential messages:

'It's all hand actions, signalling [actions used to demonstrate] like when the sun comes up take one tablet. When you go to bed - we do our hands on our face - when you go to sleep take one tablet. Those kinds of actions help ... making sure they take the right dosages, so there's no miscommunication.' (P4)

'The pharmacist and the staff will try to tell them but actually the message doesn't get through so they still get their medication like ... This one, this one [points] one a day [holds up one finger], three times a day [holds up three fingers] ..." like this, like that - they will see these fingers but actually, it doesn't get anywhere. So, when you go home ... you don't even know which one this is, which one is that, which one is which?'(RHL1)

Some refugee health leaders were unaware that pharmacists had access to the free Translating and Interpreting Service. One pharmacist was not aware of the interpreter service, although the other pharmacists were. They described specific difficulties when using an interpreter in the pharmacy:

'It's challenging even using the interpreter because usually it's the phone. And this can be a busy environment at times and there's a lot happening ... you just having the phone and trying to hear ... adds a degree of complication that's just inherent with sharing a phone around.'(P1)

Even when interpreters were used, some healthcare providers were concerned that communication could still be difficult:

'There are definitely times when people will come back and we've thought that they understood ... we always use telephone interpreters ... so we do always explain but we definitely get times when people come back and they haven't taken the complete course...'(N3)

Cultural barriers. Cultural barriers could affect quality use of medicines but providing sex-specific and culturally concordant care facilitated access for some patients:

Muslim ladies ... want to see female doctors, which can be difficult ... [A female doctor] is only there 2 days a week and not always ...'(N2)

I have had one incident where I had to get not one ... or a second one, but a third interpreter because this man wasn't happy with the first two because they were actually of lower class than him ... so he wouldn't talk to them.' (N1)

Even when the patient could speak English, professional or cultural arrogance could seriously compromise patient safety, for example, if medical information was inappropriately dismissed. One refugee health leader described her personal experience:

I had a hernia [operation] ... The next morning I have to go home but I was really painful ... Now, I am allergic, I have got allergic to lots of things ... so the next week the doctor came and give me indomethacin for painkiller and I said "can you give me different painkiller because I have lots of things allergic to me ...?" and they said "Oh everybody take it ... you have to take it". So they give it to me ... straight away I take this medication and I really want to sleep so I said that something is wrong ... and I pressed the red button and I was in intensive care for 3 days ...' (RHL2) 
Sharing medicines is a normative cultural practice for many refugees, which can influence their medicines use in Australia:

'This is what happens in my country ... "oh, I have this medication", so-and-so is sick, I can give it to them. Because it make me well, it may make them well.' (RHL1)

'Especially with antibiotics ... expensive medication, they share ... "you can take it because you are my friend so I can give it to you".' (RHL2)

This could have serious consequences:

I went to visit to give my condolences to them as a community member ... and she said she was taking medication so I asked her what kind of medication and she said ... "you know that my mum has died of cancer and she has left over so I am taking medication so / can't get the cancer". '(RHL2)

Only one health provider, a nurse, mentioned the sharing of medicines as a concern. One refugee health leader, but no healthcare providers, raised concerns about interactions between traditional and prescribed medicines:

Some people here are using prescription medication drugs with ... traditional drugs that they are using ... that can happen with the interactions. That is why I think that the pharmacists... can explain this and that so that they are more aware of that ...' (RHL2)

Limited health literacy. Poor health literacy in the refugee communities appeared to augment other barriers to quality use of medicines:

'I think a lot of them don't have a good concept ... of how medications work ... that it's important to take the medication as it is prescribed for the prescribed duration of time ... a lot of them don't, maybe, fully understand these concepts.' (GP1)

I've had refugees who are taking five times the recommended dosage. I've had refugees who didn't complete courses of anti-infectives. '(P1)

The same generic medicines are often presented differently (for example, in different packaging or being a different colourl and can confuse people with limited health literacy, compromising patient safety:

'One woman in particular was prescribed aspirin. She had gone to the chemist and got a particular brand of aspirin that wasn't 'Aspirin'; it was something else ... another doctor ... gave her a different script. She got that filled and this went on until she had six different packets of aspirin in various names ...' (N1)

Financial barriers. The cost of medicines was an access barrier for many refugee patients as described by refugee health leaders and healthcare providers. Reduced access could increase the overall health system costs:

'“'Oh. I will come back for it because I don't have this money at the moment", and then you don't come back ... You don't come back to take the medication and then that disease will not go away because it is not treated.' (RHL1)

'If they don't have the medication, their symptoms continue and their health goes downhill. So ... you know ... and then they keep coming back unnecessarily and they present to the hospital unnecessarily. (N1)

Some medications are subsidised through the national Pharmaceutical Benefits Scheme making them less expensive with a doctor's prescription than over-the-counter medications:

'Over-the-counter medicine is more difficult. It is more expensive so it is harder than if it is on prescription so often they need to go to the doctor and get a script and then it is cheaper.' (P2)

Chronic health issues may require multiple medicines so increasing the cost:

'The biggest problem is that it's expensive ... if you get people with chronic illnesses ... diabetes, hypertension, or whatever ... then they're on a range of medication so ... cost is probably the biggest thing. ' (N3)

Health providers also incurred costs due to inadequate remuneration for the extra time required to manage the refugee health consultation.

Health system barriers. Many refugees found negotiating the health system difficult, beyond the language barrier and cultural issues:

'The whole system for a lot of them is so confusing ... you know, the way it all works. The way you have got to book an appointment to be seen.' (N2) 
Medicines for some refugee health issues were not readily available at some pharmacies:

'There's a few drugs that you see for refugee health that you don't normally see with the Australian population.' (P1)

\section{Facilitators of access and quality use of medicines}

Four key themes were identified as facilitators: coordination between healthcare providers, community engagement, healthcare provider training, and providing information on medicines.

Coordination between healthcare providers. Pharmacists were considered vital by both healthcare providers and refugee health leaders to educate patients about their medicines:

II know the doctors don't have time ... that's why I think pharmacy can fill in the gap... because doctors just doesn't have time to explain thoroughly... so pharmacy has to use interpreters for that kind of situation because somebody has to fill in the gap between the patient and the medication ... that's really important.'(RHL2)

Having the GP practice and pharmacy located close to each other could enable coordination

The practice nurses had an important role facilitating collaboration between healthcare providers and providing key background information for the pharmacist:

'Refugees are a very complex group. It depends on what country they are from, what country they've left from ... a whole range of things ... understanding their culture, understanding their religions often; that's all part of it ...' (N1)

Community engagement. Both refugee health leaders and healthcare providers expressed the need to involve community leaders in educating community members:

Community members will speak their language, they speak their values, they will express the same feelings ... they trust community members ... and they will listen to their story. Whatever explanation is needed then these people can give it [education] to them rather than somebody else that they don't know that can come from anywhere and tell them what to do.' (RHL3)

Local refugee support agencies such as the local settlement agency also facilitated access to services:

We contact their case managers through the settlement agency and we keep in contact with them and they will say "we'll let them know when the appointment is ... "and then they often assist with transport ...' (N3)

Healthcare provider training. Health providers recognised that training in refugee health would improve their capacity to enable quality use of medicines, yet they had received little training:

'You actually don't get much training with regards to refugee health. So a lot of it has been pretty much "on the spot" ... I think in my first 6 months here I relied a lot on speaking to other doctors here about some of the common problems, yeah ... and a lot of the protocols as well.' (GP1)

Providing information on medicines. Providing information about medicines to refugees was considered essential to achieving quality use of medicines:

Access to medicine information in their own languages... would be probably helpful there because then if they are confused they can at least look at the side effects and that sort of thing.' (N2)

'When they bring in their box, it's got their writing on it to say when to take it and we make sure we give that back to them so they know what to write on the new box. It helps them.' (P4)

Limited literacy skills meant such interventions needed to be appropriately targeted:

'Education is the main thing. Because lots of people can't read and write, even, yeah, you give ... translated pamphlet especially for antibiotic ... Some people can't read and write their own language though.' $(\mathrm{RH} \mathrm{L} 2)$

One GP suggested that a Home Medicines Review $^{32}$ la publicly subsidised service in which a pharmacist visits the home to advise on medications) could facilitate adherence and quality use of medicines. Information could also be provided by embracing modern technologies:

I try to choose generics when I dispense because they have a QR code - you know they can use their phone and then all the information comes up ...' (P2) 
A lot of them do have access to the internet or they have iPhones ...' (N2)

'I think the SMS system is really good. We have lots of our customers on this system and it is really good for the refugee patients ... '(P3)

'There is Google Translate ... it's quite good. If someone doesn't understand something, we can take them to our computer and type it in.' (P4)

Finally, there was earnest engagement between pharmacists and their refugee clients. Compassion and understanding were crucial elements for the delivery of quality care and enabling quality use of medicines:

Sometimes it's just through talking to people you know and saying "how are you going?"... And you have to be willing to engage with them and if you're not willing to engage and actually initiate a general conversation about all the tablets you're about to give them then you probably won't ... pick up any problems then really.' (P1)

Others developed a deeper understanding of their client's journey as a refugee:

'Over time they tell you things that they have experienced that no one should experience. One man told me about his mother and she fell off the boat and they wouldn't turn the boat around and he was the last person to see... Some of them have had a very difficult time and it is good to be able to help.' (P2)

This commitment clearly aligns with the Australian Pharmacy Board's Code of Conduct: 'having knowledge of, respect for and sensitivity towards the cultural needs and background of the community: ${ }^{33}$

I think it is our humanitarian duty to extend help to people - regardless of whatever nationality or whatever culture they may be from. We want to call ourselves a "developed country", so I think it's a responsibility that you should carry... I mean, we're the lucky ones right? We put these walls around our country to maintain our wealth but I think we have to allow for it to transfer by osmosis to other people.' (P1)

\section{DISCUSSION}

\section{Summary}

This study explored the barriers and facilitators of quality use of medicines in refugee communities (Box 1), recognising that the quality use of medicines is a central tenet for the successful delivery of quality care..$^{13}$ Although this is a preliminary study, it is the first to consider quality use of medicines from the perspectives of both the healthcare providers and the refugee community. It provides specific insights that can inform structural and educational reforms to improve access and quality use of medicines for refugees (Box 2).

\section{Strengths and limitations}

The main limitations of this study relate to it being a small, preliminary study.

Data were collected from a single Australian urban community. Provincial cities and rural environments may be very different. Only a few healthcare providers from each profession were interviewed and they self-identified as having an interest in refugee health. Although they could draw on their experiences in this field, these cannot be considered representative of other healthcare providers.

Although only three refugee health leaders were interviewed, they had consulted with their communities and were very aware of their communities health needs. Although it is not possible to be certain that saturation was reached, the study is strengthened by having data from both health providers and consumers, which is unusual in health research with refugees. The concordance across the themes emerging from both providers and consumers strengthens the validity of the findings. The results also resonate strongly with previous health research on refugees. ${ }^{27,28,30,34}$

\section{Comparison with existing literature}

This study confirmed the need for clear communication when prescribing, recognising the vital role that interpreters play. ${ }^{32}$ Communication enables adherence and improves the identification of adverse effects that could compromise patient safety. ${ }^{35}$ Relying on non-verbal communication (for example, to provide dosage instructions) is inadequate. The information that needs to be exchanged goes well beyond dosage instructions and includes what other medicines are being taken and potential side effects. ${ }^{36}$ Difficulties with over-the-counter or traditional medicines were highlighted. Pictograms to support instructions on medicines for consumers with low literacy can be misinterpreted, ${ }^{37}$ especially in cross-cultural settings. Little research has explored the use of newer technologies. The International Pharmaceutical Federation recently 
Box 2. Factors that reduce barriers to quality use of medicines in refugee health care

\begin{tabular}{|c|c|c|c|c|}
\hline \multirow{2}{*}{$\begin{array}{l}\text { Theme } \\
\text { Identified barrier } \\
\text { - Language and communication }\end{array}$} & \multirow[b]{2}{*}{$\begin{array}{l}\text { Patient factors } \\
\text { Encourage patients } \\
\text { who need an } \\
\text { interpreter to } \\
\text { identify this issue } \\
\text { when making an } \\
\text { appointment. } \\
\text { Empower patients } \\
\text { to engage in the } \\
\text { shared decision- } \\
\text { making process to } \\
\text { facilitate concordance. }\end{array}$} & $\begin{array}{l}\text { Medicines factors } \\
\text { Provide relevant } \\
\text { medicines information. }\end{array}$ & $\begin{array}{l}\text { Provider factors } \\
\text { Identify linguistic } \\
\text { barriers and } \\
\text { arrange an } \\
\text { interpreter } \\
\text { when needed. }\end{array}$ & $\begin{array}{l}\text { System factors } \\
\text { Ready access to } \\
\text { interpreters for } \\
\text { patients and health } \\
\text { providers. }\end{array}$ \\
\hline & & $\begin{array}{l}\text { Provide relevant } \\
\text { medicines information. } \\
\text { Use interpreters } \\
\text { to explain } \\
\text { medication use. } \\
\text { Be aware of } \\
\text { difficulties with } \\
\text { generic prescribing. } \\
\text { Use non-verbal tools } \\
\text { and newer technologies } \\
\text { for translation cautiously. }\end{array}$ & $\begin{array}{l}\text { Identify linguistic } \\
\text { barriers and } \\
\text { arrange an } \\
\text { interpreter } \\
\text { when needed. } \\
\text { Be aware that low } \\
\text { literacy in patient's } \\
\text { first language can } \\
\text { reduce the value } \\
\text { of translated material. } \\
\text { Recognise the } \\
\text { importance of a } \\
\text { trusting relationship } \\
\text { to enable the } \\
\text { shared decision- } \\
\text { making process to } \\
\text { be effective. }\end{array}$ & $\begin{array}{l}\text { Ready access to } \\
\text { interpreters for } \\
\text { patients and health } \\
\text { providers. } \\
\text { Training for health } \\
\text { providers to use } \\
\text { interpreters. } \\
\text { Educational } \\
\text { opportunities for } \\
\text { refugees to } \\
\text { learn English. } \\
\text { Community } \\
\text { engagement to } \\
\text { develop and evaluate } \\
\text { relevant tools to } \\
\text { support medicines } \\
\text { information. }\end{array}$ \\
\hline Cultural & $\begin{array}{l}\text { Facilitate engagement } \\
\text { with local communities } \\
\text { to ensure support } \\
\text { to minimise the } \\
\text { negative impact of } \\
\text { cultural issues on } \\
\text { the quality use of } \\
\text { medicines. }\end{array}$ & $\begin{array}{l}\text { Recognise risks } \\
\text { when prescribed } \\
\text { medicines are } \\
\text { used with } \\
\text { traditional } \\
\text { medicine. } \\
\text { Understand risks } \\
\text { and identify } \\
\text { concerns around } \\
\text { sharing of medicines. }\end{array}$ & $\begin{array}{l}\text { Cross-cultural } \\
\text { training to identify } \\
\text { and manage } \\
\text { cross-cultural } \\
\text { consultations. } \\
\text { Awareness } \\
\text { that cultural issues } \\
\text { can alter the } \\
\text { interpretation of } \\
\text { support material. } \\
\text { Self-reflection } \\
\text { training to identify } \\
\text { issues as they arise } \\
\text { in the consultation. } \\
\text { Recognise issues of } \\
\text { stigma that impact on } \\
\text { refugee health care. }\end{array}$ & $\begin{array}{l}\text { Identify and address } \\
\text { cultural needs } \\
\text { of the local } \\
\text { communities } \\
\text { through community } \\
\text { engagement. } \\
\text { Community } \\
\text { engagement to } \\
\text { develop and evaluate } \\
\text { culturally appropriate } \\
\text { supports } \\
\text { for medicines use. }\end{array}$ \\
\hline Limited health literacy & $\begin{array}{l}\text { Provide patients } \\
\text { and communities } \\
\text { with opportunities to } \\
\text { increase their } \\
\text { health understanding. } \\
\text { Support patients to } \\
\text { understand the } \\
\text { need for regular } \\
\text { medication for } \\
\text { management of some } \\
\text { chronic diseases. }\end{array}$ & $\begin{array}{l}\text { Strengthen } \\
\text { understanding of } \\
\text { the purpose for } \\
\text { each medicine. } \\
\text { Ensure the treatment } \\
\text { course duration is } \\
\text { understood. } \\
\text { Beware that } \\
\text { generic medicines } \\
\text { can cause confusion. } \\
\text { Provide support for } \\
\text { return for repeat } \\
\text { prescriptions for } \\
\text { regular medications. }\end{array}$ & $\begin{array}{l}\text { Identify patients } \\
\text { with low health } \\
\text { literacy complicating } \\
\text { linguistic barriers. } \\
\text { Identify } \\
\text { opportunities } \\
\text { to consistently } \\
\text { build individual } \\
\text { health literacy. }\end{array}$ & $\begin{array}{l}\text { Identify and address } \\
\text { health literacy needs } \\
\text { of the local } \\
\text { communities } \\
\text { through } \\
\text { community } \\
\text { engagement. } \\
\text { Provide education } \\
\text { about the role } \\
\text { of different } \\
\text { health providers. } \\
\text { Enable community } \\
\text { understanding } \\
\text { of the safe use } \\
\text { of medicines. }\end{array}$ \\
\hline
\end{tabular}

produced guidelines for pharmacists caring for migrants providing access to pictograms and translated instructions. ${ }^{38}$ Community engagement is essential to ensure the development and evaluation of safe and effective tools. 


\section{Box 2 continued. Factors that reduce barriers to quality use of medicines in refugee health care}

\begin{tabular}{|c|c|c|c|c|}
\hline Theme & Patient factors & Medicines factors & Provider factors & System factors \\
\hline Financial & $\begin{array}{l}\text { Empower refugees } \\
\text { to discuss the } \\
\text { issues of cost } \\
\text { with their doctor. } \\
\text { Identify supports in } \\
\text { the community } \\
\text { to assist with } \\
\text { costs. }\end{array}$ & $\begin{array}{l}\text { Minimise costs } \\
\text { of common } \\
\text { medications required } \\
\text { for early acute } \\
\text { health issues and } \\
\text { chronic disease. }\end{array}$ & $\begin{array}{l}\text { Incentive payments } \\
\text { for provider. } \\
\text { Be mindful } \\
\text { of costs when } \\
\text { prescribing or } \\
\text { dispensing medicines } \\
\text { (prescribed and } \\
\text { over-the-counter). }\end{array}$ & $\begin{array}{l}\text { Provide financial } \\
\text { support for } \\
\text { refugees' access } \\
\text { to medications. } \\
\text { Provide financial } \\
\text { incentives for } \\
\text { pharmacies and } \\
\text { general practices } \\
\text { providing refugee } \\
\text { health care. }\end{array}$ \\
\hline Health system & $\begin{array}{l}\text { Provide patients } \\
\text { with opportunities } \\
\text { to increase their } \\
\text { understanding of } \\
\text { their local health } \\
\text { system to enhance } \\
\text { access and optimise } \\
\text { use of relevant } \\
\text { health services. } \\
\text { Encourage patients } \\
\text { to have a regular } \\
\text { pharmacist and GP } \\
\text { who understand their } \\
\text { personal medicines. }\end{array}$ & $\begin{array}{l}\text { Recognise risk } \\
\text { of non-adherence } \\
\text { and support } \\
\text { medicines use. }\end{array}$ & $\begin{array}{l}\text { Be aware of low } \\
\text { health system } \\
\text { literacy when } \\
\text { providing medicines } \\
\text { information. } \\
\text { Actively engage } \\
\text { with local } \\
\text { health } \\
\text { professionals } \\
\text { to maximise } \\
\text { collaborative } \\
\text { care. } \\
\text { Recognise and } \\
\text { strengthen the } \\
\text { role of the practice } \\
\text { nurse in optimising } \\
\text { quality use of } \\
\text { medicines. }\end{array}$ & $\begin{array}{l}\text { Identify pharmacies } \\
\text { with expertise } \\
\text { in refugee health. } \\
\text { Identify opportunities } \\
\text { to facilitate } \\
\text { interprofessional } \\
\text { collaborative care } \\
\text { within and between } \\
\text { primary care } \\
\text { providers. } \\
\text { Locate pharmacies } \\
\text { and general } \\
\text { practices in } \\
\text { close proximity. } \\
\text { Provide refugee } \\
\text { communities with } \\
\text { opportunities to } \\
\text { increase their } \\
\text { understanding } \\
\text { related to the } \\
\text { local health system } \\
\text { to enhance access } \\
\text { and optimise use of } \\
\text { relevant health services. }\end{array}$ \\
\hline
\end{tabular}

In Australia, GPs and pharmacists have access to free interpreters through the national Translating and Interpreting Service. ${ }^{39}$ This service is under-used, ${ }^{39}$ despite interpreters being encouraged in the pharmacists' Code of Conduct. ${ }^{33}$ Pharmacists encounter significant obstacles integrating the use of interpreters into their practice. ${ }^{40}$ Access to interpreters can be difficult and environmental factors can negatively impact upon using an interpreter..$^{40}$ Health provider training is required to enable interpreter use and delivery of cross-cultural care. $22,34,39,40$ Addressing cultural difference can improve quality use of medicines. This study provides further support for delivering cross-cultural awareness training for health practitioners. ${ }^{27,41}$
Powerful narratives captured in this study illustrate the potentially serious health, social, and financial consequences that can result when health providers fail to identify and manage cultural dissonance. Although common cultural practices, such as the sharing of medicines and the simultaneous use of traditional medicines, have been reported previously, they may not be recognised by providers. ${ }^{23,41}$ Poor health literacy is common in refugee communities ${ }^{28,32}$ and community education can address this. ${ }^{27}$ Refugee health leaders clearly described how community leaders should be engaged as trusted sources of information to facilitate education to optimise medicines use. Although written information is useful, poor literacy in a person's first language can limit the 
effectiveness of translated resources..$^{40}$ Refugees might benefit from a medication review with a pharmacist, which could improve patient safety. ${ }^{32}$

Financial barriers are complex and exist for both refugees and health providers. Health providers need to understand how costs, such as transport, can hinder access. Similarly, the high costs of overthe-counter medicines can drive medical presentations as patients seek subsidised prescription items. ${ }^{42}$ Incentive payments have been championed previously to address the limited remuneration provided to health providers (pharmacists and GPs) who dedicate extra time caring for refugees in the private sector. ${ }^{38,42,43}$

Collaboration between healthcare providers can enable quality use of medicines. ${ }^{15}$ This study recognises the significant role of pharmacists in delivering health care for refugees. The role of the practice nurse in supporting this collaboration appears under-recognised and further exploration is recommended.

\section{Implications for research and practice}

Optimising the use of medicines to enhance the quality of health care for refugees has global relevance. ${ }^{44}$ Despite its preliminary nature, this study has articulated practical strategies that can be implemented locally, recognising that a multifaceted approach involving patients, communities, and health providers is ideal (Box 2). Evaluation of these strategies, with community engagement, is essential to progress a more systemic approach. Although current policies and guidelines address specific concerns of other vulnerable groups such as older patients, the issues raised in this paper are rarely considered. ${ }^{12-15,45}$ These issues also relate to other culturally and linguistically diverse communities, not only refugees. Such policies need to be strengthened to facilitate the implementation of relevant strategies and enable further research in this emerging field.

\section{Funding}

None provided.

\section{Ethical approval}

Ethics approval was granted from the University of Queensland Behavioral \& Social Sciences Ethical Review Committee (No. 20133001442)

\section{Provenance}

Freely submitted; externally peer reviewed.

\section{Competing interests}

The authors have declared no competing interests.

\section{Acknowledgements}

Thanks to all the interviewees for their participation and their invaluable input. Thanks also to UQ Health Care, Annerley, Brisbane, for providing research support for Harriet Cook during this study.

\section{Discuss this article}

Contribute and read comments about this article: bjgp.org/letters 


\section{REFERENCES}

1. Gostin LO, Roberts AE. Forced migration: the human face of a health crisis. JAMA 2015; 314(20): 2125-2126

2. Rechel B, Mladovsky P, Devillé W, et al, eds. Migration and health in the European Union. European Observatory on Health Systems and Policies series. Maidenhead: Open University Press, 2011.

3. Adams KM, Gardiner LD, Assefi N. Healthcare challenges from the developing world: post-immigration refugee medicine. BMJ 2004; 328(7455): 1548-1552.

4. Johnston V, Smith L, Roydhouse $H$. The health of newly arrived refugees to the Top End of Australia: results of a clinical audit at the Darwin Refugee Health Service. Aust J Prim Health 2012; 18(3): 242-247.

5. Martin JA, Mak DB. Changing faces: a review of infectious disease screening of refugees by the Migrant Health Unit, Western Australia in 2003 and 2004. Med J Aust 2006; 185(11-12): 607-610.

6. United Nations High Commissioner for Refugees. Frequently asked questions about resettlement. Geneva: UNHCR, 2012. http://www.unhcr.org/cgi-bin/texis/ vtx/home/opendocPDFViewer.html?docid=4ac0873d6 (accessed 12 Apr 2016).

7. Bates DW. Primary care and the US health care system: what needs to change? $J$ Gen Intern Med 2010; 25(10): 998-999.

8. De Maeseneer J, Willems S, De Sutter A, et al. Primary health care as a strategy for achieving equitable care: a literature review commissioned by the Health Systems Knowledge Network. Geneva: WHO, 2007. http://www.who.int/social determinants/publications/healthsystems/en/ (accessed 12 Apr 2016).

9. Starfield B. The hidden inequity in health care. Int J Equity Health 2011; 10: 15

10. Royal College of General Practitioners. Asylum seekers and vulnerable migrants. London: RCGP, 2013. http://www.rcgp.org.uk/policy/rcgp-policy-areas/asylumseekers-and-vulnerable-migrants.aspx (accessed 12 Apr 2016).

11. Department of Health and Ageing. National primary health care strategic framework. Canberra: Standing Council on Health, 2013. http://www.health.gov. au/internet/main/publishing.nsf/Content/nphc-strategic-framework laccessed 12 Apr 2016).

12. National Institute for Health and Care Excellence. Medicines optimisation: the safe and effective use of medicines to enable the best possible outcomes. NG5. London: NICE, 2015.

13. Department of Health and Ageing. National medicines policy 2000. Canberra: Australian Government, 1999. http://www.health.gov.au/internet/main/publishing. nsf/Content/B2FFBF72029EEAC8CA257BF0001BAF3F/\$File/NMP2000.pdf (accessed 12 Apr 2016).

14. Institute for Safe Medication Practices. Improving medication safety in community pharmacy: assessing risk and opportunities for change. Horsham, PA: ISMP, 2009. http://www.ismp.org/communityRx/aroc/ laccessed 12 Apr 2016).

15. Duerden M, Millson D, Avery A, Smart S. The quality of GP prescribing. An inquiry into the quality of general practice in England. London: King's Fund, 2011. http:// uww.kingsfund.org.uk/sites/files/kf/field/field_document/quality-gp-prescribinggp-inquiry-research-paper-mar11.pdf (accessed 12 Apr 2016).

16. Department of Health and Ageing. The national strategy for quality use of medicines. Plain English edition. Canberra: Australian Government, 2002. http://www.health.gov.au/internet/main/publishing.nst/ Content/8ECD6705203E01BFCA257BF0001F5172/\$File/natstrateng.pdf laccessed 12 Apr 2016).

17. Mullen PD. Compliance becomes concordance. Making a change in terminology produce a change in behaviour. BMJ 1997; 314(7082): 691-692.

18. Van Wijk BL, Klungel OH, Heerdink ER, de Boer A. Effectiveness of interventions by community pharmacists to improve patient adherence to chronic medication: a systematic review. Ann Pharmacother 2005; 39(2): 319-328.

19. Bell S, McLachlan AJ, Aslani P, et al. Community pharmacy services to optimise the use of medications for mental illness: a systematic review. Aust New Zealand Health Policy 2005; 2: 29.

20. Pottie K, Greenaway C, Feightner J, et al. Evidence-based clinical guidelines for immigrants and refugees. CMAJ 2011; DOI: 10.1503/cmaj.090313.

21. Yun K, Hebrank K, Graber LK, et al. High prevalence of chronic noncommunicable conditions among adult refugees: implications for practice and policy. J Community Health 2012; 37(5): 1110-1118.

22. Betancourt JR, Green AR, Carrillo JE, Ananeh-Firempong 0 2nd. Defining cultural competence: a practical framework for addressing racia//ethnic disparities in health and health care. Public Health Rep 2003; 118(4): 293-302.

23. Bellamy K, Ostini R, Martini N, Kairuz T. Access to medication and pharmacy services for resettled refugees: a systematic review. Aust J Prim Health 2015;
21(3): 273-278.

24. Department of Immigration and Border Protection. Part 3: Report on performance. In: Annual Report 2013-2014. Canberra: Department of Immigration and Border Protection, 2014: 25-238.

25. Cheng $\mathrm{IH}$, Drillich $\mathrm{A}$, Schattner P. Refugee experiences of general practice in countries of resettlement: a literature review. Br J Gen Pract 2015; DOI: 10.3399/ bjgp15X683977.

26. Sheikh-Mohammed M, Macintyre C, Wood NJ, et al. Barriers to access to health care for newly resettled sub-Saharan refugees in Australia. Med J Aust 2006; 185(11-12): 594-597.

27. Clark A, Gilbert A, Rao D, Kerr L. 'Excuse me, do any of you ladies speak English?' Perspectives of refugee women living in South Australia: barriers to accessing primary health care and achieving the Quality Use of Medicines. Aust J Prim Health 2014; 20(1): 92-97.

28. Russell G, Harris M, Cheng I, et al. Coordinated primary health care for refugees: a best practice framework for Australia. Canberra: Australian Primary Health Care Research Institute, 2013. files.aphcri.anu.edu.au/reports/Grant\%20 RUSSELLFinal\%20Report.pdf laccessed 12 Apr 2016).

29. Mater Health Services. South East Queensland Refugee Health Partnership Advisory Group (RH-PAG). http://www.materonline.org.au/services/refugeeservices/refugee-health-resources/resources-for-general-practice-clinicians/ groups-and-networks laccessed 12 Apr 2016).

30. Department of Social Services. Migration stream by local government area. Canberra: Department of Social Services, 2015. https://uww.dss.gov.au/ourresponsibilities/settlement-and-multicultural-affairs/settlement-reportingfacility/settlement-quick-reports/migration-stream-by-local-government-area laccessed 12 Apr 2016).

31. Pope C, Mays N, eds. Qualitative research in health care. 3rd edn. Malden, MA: Blackwell Publishing, 2006

32. Smith M, Lo W, Bindra J. Prescribing for refugees. Aust Prescriber 2013; 36: 146-147.

33. Pharmacy Board of Australia. Code of conduct. Melbourne: Australian Health Practitioner Agency, 2014. http://www.pharmacyboard.gov.au/Codes-Guidelines/ Code-of-conduct.aspx laccessed 12 Apr 2016).

34. Farley R, Askew D, Kay M. Caring for refugees in general practice: perspectives from the coalface. Aust J Prim Health 2014; 20(1): 85-91.

35. Britten N. Medication errors: the role of the patient. Br J Clin Pharmacol 2009; 67(6): 646-650.

36. Avery AJ, Sheikh A, Hurwitz B, et al. Safer medicines management in primary care. Br J Gen Pract 2002; 52(Suppl): S17-S22.

37. Davis TC, Wolf MS, Bass PF 3rd, et al. Low literacy impairs comprehension of prescription drug warning labels. J Gen Intern Med 2006; 21(8): 847-851.

38. International Pharmaceutical Federation. Providing pharmaceutical care to migrant populations, 2015: information and guidelines for pharmacists and the pharmacy workforce. The Hague, The Netherlands: FIP, 2015. http://fip.org/files/ fip/emergencies/MigrantsGuidelines.pdf (accessed 12 Apr 2016).

39. Phillips C. Using interpreters: a guide for GPs. Aust Fam Physician 2010; 39(4): 188-195.

40. Young HN, Dilworth TJ, Mott DA, et al. Pharmacists' provision of information to Spanish-speaking patients: a social cognitive approach. Res Social Adm Pharm 2013; 9(1): 4-12

41. Bhatia R, Wallace P. Experiences of refugees and asylum seekers in general practice: a qualitative study. BMC Fam Pract 2007; 8: 48.

42. Parmentier H, Golding S, Ashworth M, Rowlands G. Community pharmacy treatment of minor ailments in refugees. J Clin Pharm Ther 2004; 29(5): 465-469.

43. Hargreaves S, Holmes A, Friedland JS. Refugees, asylum seekers, and general practice: room for improvement? Br J Gen Pract 2000; 50(456): 531-532.

44. World Health Organization Regional Office for Europe. Refugee crisis, situation update, 2. Copenhagen: WHO, 12 October 2015. http://mww.euro.who.int/_data/ assets/pdf_file/0010/290179/WHO-Situation-Update-Refugee-Crisis-2-DraftVersion-4-1.pdf (accessed 12 Apr 2016).

45. Royal Pharmaceutical Society. Medicines optimisation: helping patients to make the most of medicines. Good practice guidance for healthcare professionals in England. London: RPS, 2013. http://www.rpharms.com/promoting-pharmacy$\mathrm{pdfs} /$ helping-patients-make-the-most-of-their-medicines.pdf laccessed $12 \mathrm{Apr}$ 2016). 


\section{Appendix 1. Barriers and facilitators relating to access to and quality use of medications for people of refugee background}

\section{Theme}

Language and communication barriers

That is, issues related to linguistic diversity and communication

\section{Example}

'I find that having an interpreter on-site is better than having a phone interpreter ... 'GP1)

I have only used the telephone interpreter once and I had to wait a long time on the phone and they kept saying I would have to pay and said no I didn't and then it took a long time and they said I would have to pay. It didn't work very well.'(P2) 'There could be specific pharmaceutical interpreters that may be perhaps more beneficial because usually the interpreters very often they have some knowledge ... but sometimes not, of medical issues of drugs. '(GP2) I never see [an interpreter] in pharmacy... never in pharmacy! Only sometimes the interpreter can give the favour to clients ...' (RHL2)

When it's prescribed they would explain it to you more but when it's just over-the-counter ... there's no more explanation ... '(RHL1) You can ask a question which is maybe complex and then has the interpreter interpreted that question as I wanted asked and then is the answer that comes back, the answer to the question which I think that I have asked or not? That just makes an overall assessment ... more tricky.' (GP2)

\section{Cultural barriers}

'I think there's always the cultural differences in the understanding of medicines ... you know, you'll get some cultural That is, issues related to cultural difference including cultural expectations and cultural practices

\section{afraid of it.' (N3)}

'I think cultural things are an issue too - especially with the African ladies ... they seem to be quite shy of talking to men ... so it's very hard to engage or get them to engage.' (P1)
When I came to Australia ... I can speak English ... I was really afraid of hospitals and I didn't go out at all... my jaw was stuck ... at that time I can't speak, I would just cry and go home... That is why these days I fight for the people, even these refugees who can speak English ...'(RHL2)

'If somebody is sick in the same scenario, and they think it is the same then they will give them [the same medicine] the reason they do that is that they can go and buy medication from anybody... somebody could be on the street back home and they can buy medication from them ... not here. '(RHL3)

'They will share their medication ... like I've heard stories about TB medication ... they will take it home and they will share it amongst all the family...'(N1)

\section{Limited health literacy}

That is, issues related to reduced health knowledge

\section{Financial barriers}

That is, issues related to cost of medications

\section{Health system barriers}

That is, issues related to understanding and navigating the health system

I think a big problem is all the generic brands because it is very confusing ... they go and get their tablets ... one sort and they're yellow or whatever and then the next time they are white ... and then they are very confused ... '(N2)

I think you are limited to Pharmaceutical Benefits System (BPS) medications. Anything that is going to be privately funded is usually not really an option.' (GP1) With the "bridging visa" refugees - they don't have the money to buy their scripts ...' (N1)

Another thing is the health system ... different health system in this country ... '(RHL2) 'We don't have the rules and all the laws about drugs ... you can buy anything ...'(RHL2)

'They need to understand the system a bit ... that's the main problem. Many of them don't even go to the doctor ... '(RHL3)
'Because they're catching public transport they are 2 hours later [for their appointment] so obviously those are issues... '(N2) 'They're [GPs are] not really happy ... they'd rather have another patient than a refugee because they ... because it is difficult, it's difficult.' (N2)

'You sort of feel like you've got the doctors that are interested and then you've got some doctors that just aren't... I don't know whether it's because of the difficulties or because of the language barriers or because it's not financially rewarding I think that's an area where ... it's a big limitation in terms of outcomes for refugees. '(GP1)

You have to spend a lot more time with these patients when it comes to medications compared to the general population. '(GP1)

You have to be far less rushed. You have to take much more time and care explaining what the medicines are. I would like to think that the chemists do it too ... and I know the one next door to me does ... I don't know about other chemists. '(N1) 'Time is a major issue. It's usually, I think, these people need more time spent with them than we probably have to offer sometimes but, you know, you have to do the best you can ...' (P1)

\section{Coordination between} healthcare providers That is, interprofessional communication or engagement impacting on medication use
'[The pharmacist] next door, he's really very good and, you know, we work with them and they will make sure that they come back ...'(N2)

"If you get your medicine prescribed here the doctor says "go here ... if there is any difficulties come back". So, that's what I have found through my interpreting is very important because if they don't get anything here then they come back to the doctor and they rectify it.' (RHL1)

'If we find that they don't understand or if we don't know what exactly they're after, we always go to the nurses, or the doctors next door.' (P4)

'The more providers, the more professionals that are involved, I think, generally, the better ... you know, you have a lot more opportunity to review, to make sure that they are using their medication correctly, you know ... '(GP1)

'[GP] gets me into the consultations because he can't understand the interpreters, let alone the patients. And it's all about speaking more slowly... slowing your speech down so that you can understand them ...' (N1)

At some places there are these good nurses who go straight away with them to the pharmacies and will explain them what is needed so the patient would sit there and the nurse will take their prescription and ... tell them how to take it ... '(RHL1) 


\section{Appendix 1 continued. Barriers and facilitators relating to access to and quality use of medications for people \\ of refugee background}

\section{Theme}

Community engagement

That is, assistance with medication

issues provided by community

organisations

Healthcare provider training

That is, formal education about

cross-cultural communication

Provision of medicines

Provision of medicines

information

That is, providing information

about taking the medicines,

returning for a repeat prescription,

or understanding the medicine

\section{Example}

If there are problems we usually ring [Local Settlement Agency] and then they can help ... It is easier to ring

[Local Settlement Agency] and the caseworker and they know the client ... they seem happy to help... (P2)

No, we really haven't [had training in refugee health] it's something that we have just sort of picked up as we go along.' (P1)

Back when we were studying at uni, we learnt about different cultures and ... how they react and what people do and how to communicate with them but not extensive training ... like that would probably not be half an hour's worth ...'(P4)

Now l'm saying to them ... you put a reminder in your phone that you need to come and see me or a doctor on a date. '(N1)

Something, you know, similar to a Home Medicines Review... I think that would be cost-effective ... I think that would be a very beneficial thing ...' (GP1)

$N=$ practice nurse. $P=$ pharmacist. $R H L=$ refugee health leader. 